\title{
The creation and management of innovation in healthcare
}

Citation for published version (APA):

Schee genannt Halfmann, S. (2019). The creation and management of innovation in healthcare: the example of Personalised Medicine. [Doctoral Thesis, Maastricht University]. ProefschriftMaken Maastricht. https://doi.org/10.26481/dis.20191217ss

Document status and date:

Published: 01/01/2019

DOI:

10.26481/dis.20191217ss

Document Version:

Publisher's PDF, also known as Version of record

\section{Please check the document version of this publication:}

- A submitted manuscript is the version of the article upon submission and before peer-review. There can be important differences between the submitted version and the official published version of record.

People interested in the research are advised to contact the author for the final version of the publication, or visit the DOI to the publisher's website.

- The final author version and the galley proof are versions of the publication after peer review.

- The final published version features the final layout of the paper including the volume, issue and page numbers.

Link to publication

\footnotetext{
General rights rights.

- You may freely distribute the URL identifying the publication in the public portal. please follow below link for the End User Agreement:

www.umlib.nl/taverne-license

Take down policy

If you believe that this document breaches copyright please contact us at:

repository@maastrichtuniversity.nl

providing details and we will investigate your claim.
}

Copyright and moral rights for the publications made accessible in the public portal are retained by the authors and/or other copyright owners and it is a condition of accessing publications that users recognise and abide by the legal requirements associated with these

- Users may download and print one copy of any publication from the public portal for the purpose of private study or research.

- You may not further distribute the material or use it for any profit-making activity or commercial gain

If the publication is distributed under the terms of Article $25 \mathrm{fa}$ of the Dutch Copyright Act, indicated by the "Taverne" license above, 


\section{SUMMARY}


Summary 
To leapfrog into a future of sustainable growth, there is a pressing need to find new sources of growth to address the many economic, environmental and societal challenges Europe and the rest of the world are currently facing. Innovation will play an important role in addressing those challenges and is therefore receiving increasing attention on local, national and international levels from different stakeholders such as policy makers, researchers, industry, non-governmental organisations and the civil society.

Innovation policies not only matter for economic growth, but also for healthcare, the environment and many other areas. However, even though the benefits of innovation are well known and widely described in literature, these benefits do not always reach the society because many innovations end in the Death Valley of innovation during the process. Therefore, it is important to ask the question: are we doing the right things right?

In the past, the relation between innovation and economic growth has been studied in more detail compared to other policy areas such as healthcare. Against this background, research has been conducted to describe the innovation process and the current landscape of innovation in Europe in more detail. The focus of the thesis is on innovations in healthcare and the impact innovations can have on healthcare systems and the well-being of the citizens. The approach of Personalised Medicine (PM) was discussed in more detail as one current example of innovation in healthcare. Research was conducted to analyse the current status of the implementation and uptake of PM in Europe. This was done by applying the innXchange innovation wheel, which is explained in more detail in Chapter 2. The framework provides guidance on the essential parts and principles of innovation creation and innovation management. PM was chosen as an example since this innovative healthcare approach has great potential to address many of the healthcare challenges we are facing. Several parts of the innovation wheel have been analysed to identify factors which are either hindering or facilitating the uptake of this innovative healthcare approach.

\section{Part 1: Current landscape of innovation}

In the first part of the dissertation (Chapter 2 and 3), the current innovation landscape was analysed, and gaps and needs were identified. The findings indicated that besides its great 
potential, innovation is often hampered due to a lack of systematic stakeholder collaboration and engagement throughout the whole innovation process. In addition, the importance of the innovation ecosystem which largely determines the success of the innovation process was highlighted. In such an innovation ecosystem a variety of different actors such as large and small enterprises, policy makers, academics and the civil society participate and collaborate from local level up to international level. Moreover, infrastructure, education, a skilled workforce, regulation and legislation and innovation funding schemes are all important pillars of the ecosystems. In addition, creativity, societal norms and values and attitudes towards innovation are of equal importance for the success of the innovation process. The research findings indicated that many of those factors are often lacking in the innovation ecosystems in Europe limiting innovation capacity.

The studies revealed the importance of open, frugal mindsets for successful innovation and that the landscape of innovation has drastically changed over the last few years. Being a top innovator is no longer necessarily linear associated with R\&D spending's. New emerging lowcost innovation approaches such as frugal innovation are currently challenging mature markets and have great potential to address the many challenges the world is facing. Several examples of frugal innovation and how they impact the lives of millions of people are described in more detail in Chapter 3. Moreover, the results of the studies highlighted that due to the complexity of innovation and the many different aspects of which are influencing the innovation process, that there is no one-size fits all innovation approach.

\section{Part 2: Application of the innXchange innovation wheel to analyse the uptake and implementation of Personalised Medicine in Europe}

Over the last years, PM has become a reality and is successfully applied in various medical fields and therefore is no longer an abstract healthcare approach. Although there are success stories of implementing PM, several challenges need to be addressed to further implement and make full use of the potential of PM. By applying, the theoretical framework of the thesis, the innXchange innovation wheel, the current situation of the adaption and implementation of PM in Europe is analysed in more detail. Factors that are currently hindering or facilitating the uptake of PM are described and highlighted in Chapter 4-7. Analysing parts of the 
innXchange innovation wheel in more detail provided insights into whether we are currently doing the right things right or whether some of our actions have negative impact on the uptake of personalized medicine in Europe.

Several challenges impacting the uptake of PM have been highlighted throughout the research performed in this dissertation and the discussion i.e. funding approaches which focus almost exclusively on basic research; silo mentality; outdated regulation and legislation; PM is not yet truly individualized.

To overcome the identified barriers that are currently slowing down the innovation process and the uptake and implementation, the importance of systematic early dialogue is emphasized in this dissertation. It will be of great importance that all relevant stakeholders are collaborating from the early beginning in order to further strengthen the uptake of PM. The innXchange innovation wheel provides a tool to incorporate systematic early dialogue as key pillar into the innovation process.

Only if all stakeholders start collaborating in the innovation process on local, national and international level from the early beginning, the benefits of PM will reach the patients and healthcare systems and our actions will be fit-for-purpose to make Europe a leading innovator and to further strengthen the uptake of PM. In addition, health data cooperatives; virtual twins; $\mathrm{N}=1$ trials and flexible market authorization models are disruptive solutions and will improve the uptake and implementation of PM. 
